\title{
PENERAPAN MODEL PEMBELAJARAN INKUIRI TERBIMBING TERHADAP HASIL BELAJAR PESERTA DIDIK PADA MATERI KOLOID
}

\author{
Application Of Guided Inquiry Model On Student Learning On Coloid \\ Materials
}

\author{
Raida Fadia Putri*, Bambang Suharto, Rusmansyah \\ Program Studi Pendidikan Kimia FKIP Universitas Lambung Mangkurat, \\ Jl. Brigjend. H. Hasan Basry Banjarmasin 70123 Kalimantan Selatan Indonesia \\ *email: raidafadiaputri@gmail.com
}

\begin{abstract}
Abstrak. Penelitian ini bertujuan mengetahui perbedaan signifikan hasil belajar pada peserta didik kelas XI IPA dengan penerapan model pembelajaran, yaitu model inkuiri terbimbing dan inkuiri konfirmasi. Kegiatan ini menggunakan quasi experiment dengan "pretest-posttest nonequivalent control group design". Sampel yaitu peserta didik kelas XI IPA 1 dan XI IPA 2. Pengumpulan data menggunakan teknik non-tes dan tes melalui analisis inferensial dan deskriptif. Hasil dari penelitian menunjukkan, terdapat perbedaan hasil belajar peserta didik ranah pengetahuan kelas eksperimen dengan persentase ketuntasan 30\% dan kelas control dengan persentase ketuntasan 3,7\%.
\end{abstract}

Kata kunci: inkuiri terbimbing, hasil belajar, koloid.

\begin{abstract}
The purposeeof this study was to determine the significant differences in learning result in students of class XI Science with the application of learning models, namely guided inquiry models and confirmation inquiry. This activity uses a quasi experiment with "pretest-posttest nonequivalent control group design". Samples are students of class XI IPA 1 and XI IPA 2. Data collection using non-test techniques and tests through inferential and descriptive analysis. The results of the study indicate, there are the difference in learning outcomes of the students in the realm of experimental class with $30 \%$ completeness and control class with $3.7 \%$ completeness.
\end{abstract}

Keywords: guided Inquiry, misconception, coloid materials.

\section{PENDAHULUAN}

Pendidikan adalah suatu proses perubahan perilaku seseorang dalam usaha mendewasakan diri melalui upaya pengajaran dan pelatihan menururt Diantara \& Supraptono (2016). Peserta didik saat ini juga kurang mandiri untuk memperoleh fafta dan informasi melalui membaca literatur, sedangkan saat pembelajaran peserta didik dituntut berperan aktif, bersemangat belajar dan senantiasa memiliki rasa ingin tahu yang tinggi, hal ini sejalan dengan penelitian Supardi (2013); Arief, Maulana, \& Sudin (2016). Peran aktif peserta didik ditekankan pada proses yang dilalui dalam mencapai tujuan pembelajaran, tidak hanya berfokus pada penguasaan materi(Hidayati, Leny, \& Iriani, 2018).

Salah satu materi koloid meliputi sifat-sifat koloid dan penerapannya dalam kehidupan sehari-hari, membuat peserta didik sulit meningkatkan hasil belajar yang mengharuskan menggunakan model pembelajaran yang aktif, mengharapkan peserta didik lebih mudah memahami materi karena peserta didik memiliki pengalaman dalam memecahkan masalahnya sendiri, dan peserta didik merasa menemukan model pembelajaran yang menyenangkan dan memotivasi peserta didik untuk aktif dalam

Copyright @ JCAE-Jurnal Tugas Akhir Mahasiswa, e-ISSN 2613-9782

Program Studi Pendidikan Kimia FKIP Universitas Lambung Mangkurat 
pembelajaran yang berdampak terhadap hasil belajar yang sesuai dengan yang diharapkan (Sukma, Komariyah, \& Syam, 2016).

Hasil belajar peserta didik lebih mudah menggunakan yang namanya model pembelajaran, salah satunya inkuiri terbimbing yang cocok digunakan untuk materi koloid yang selaras oleh penelitian Andrianie, Sudarmin, \& Wardani (2018); Fajarianingtyas \& Yuniastri (2015) dan Mualifah, Suyono \& Yuanita (2013) karena model tersebut membantu peserta didik memahami materi kimia yang abstrak baik secara konsep maupun perhitungan dengan mencari fakta, konsep maupun prinsip dengan benar. Pembelajaran inkuiri terbimbing membimbing peserta didik untuk memiliki tanggung jawab individu dan tanggung jawab dalam kelompok atau pasangannya (Ambarsari, Santosa, \& Maridi, 2013).

Beberapa hasil penelitian menunjukkan bahwa pembelajaran dengan menggunakan model inkuiri terbimbing dapat meningkatkan hasil belajar kognitif peserta didik, dan pengaruh inkuiri terbimbing terhadap hasil belajar peserta didik sejalan penelitian Paralita, Eny, \& Rahmat (2015) dan Syafitri (2010). Tujuannya adalah untuk mengetahui hasil belajar kimia peserta didik dengan model inkuiri terbimbing lebih baik dibandingkan peserta didik yang menggunakan model pembelajaran inkuiri konfirmasi.

Berdasarkan pemaparan di latar belakang betapa sulitnya meningkatkan hasil belajar kognitif peserta didik dan pengaruh inkuiri terbimbing terhadap hasil belajar peserta didik, membuat peneliti tertarikkmelakukannpenelitianyyang bertujuannuntuk mengetahuii Apakah terdapat perbedaan hasil belajar yang signifikan antara pembelajaran yang menerapkan model inkuiri terbimbing (guided inquiry) dan pembelajaran yang menerapkan model inkuiri konfirmasi pada materi Koloid kelas XI Ipa di SMA PGRI 6 Banjarmasin tahun pelajaran 2018/2019 menggunakanndua model yang berbeda, yaitu inkuiri terbimbing dan inkuiri konfirmasi materi larutan penyangga.

\section{METODE PENELITIAN}

Penelitian ini menggunakan metode quasi experimental dan desain penelitian berupa pretest-posttest control group design. Pengambilan sampel menggunakan teknik purposive sampling atas dasar saran guru kimia di SMA PGRI 6 Banjarmasin. Penelitian ini dilaksanakan dari bulan Desember 2018 sampai Mei 2019 di SMA SMA PGRI 6 Banjarmasin pada kedua kelas yang berbeda, yaitu kelas XI IPA 1 merupakan kelas eksperimen sebanyak 19 orang dan XI IPA 2 kelas kontrol sebanyak 26 orang. Kegiatan pengajaran dilakukan sebanyak empat pertemuan pada setiap kelas. Penilaian pada penelitian dengan teknik tes yang dilakukan pada pertemuan awal (pretest) dan pertemuan akhir penelitian (post-test), dengan analisis deskriptif dan inferensial. Perangkat penelitian berupa silabus, RPP, LKPD, alat praktikum dan lembar penilaian.

Hasil belajar peserta didik dianalisis menggunakan instrumen tes dan nontes. Instrumen tes yang dimaksut untuk mengukur ranah pengetahuan, instrument non-tes dimaksut untuk mengamati faktor-faktor yang sudah didaftar secara sistematis dan sudah diatur menurut kategorinya sejalan dengan penelitian Arikunto (2015) dan Sugiyono (2015). Teknik analisis hasil belajar pengetahuan peserta didik yang berorientasi pada kemampuan literasi ilmiah pada materi koloid. Kriteria yang digunakan untuk memberikan predikat tingkat hasil belajar ranah pengetahuan peserta didik adalam penelitian ini berdasarkan Tabel 1 dengan SKBM $<75$ tidak tuntas dan $\geq 75$ tuntas. 
Tabel 1 Konversi hasil belajar ranah pengetahuan

\begin{tabular}{cc}
\hline $\begin{array}{c}\text { Nilai Ranah Pengetahuan } \\
\text { Kategori }\end{array}$ & $\begin{array}{c}\text { Nilai Ranah Pengetahuan } \\
\text { Kategori }\end{array}$ \\
$\geq 93$ & Sangat baik \\
$84-92$ & Baik \\
$75-83$ & Cukup \\
$66-74$ & Kurang baik \\
$<66$ & Tidak baik \\
\hline
\end{tabular}

\section{HASIL PENELITIAN DAN PEMBAHASAN}

A. Hasil pre-test dan post-test Hasil Belajar Ranah Pengetahuan Peserta Didik Hasil belajar ranah pengetahuan terdapat di Tabel 2.

Tabel 2 Standar ketuntasan belajar mengajar

\begin{tabular}{ccccc}
\hline \multirow{2}{*}{ Nilai } & \multicolumn{2}{c}{ Kelas ekperimen } & \multicolumn{2}{c}{ Kelas Kontrol } \\
\cline { 2 - 5 } & Pre-test & Post-test & Pre-test & Post-test \\
\hline$<75$ & 20 & 14 & 27 & 26 \\
$\geq 75$ & - & 6 & - & 1 \\
Ketuntasan $(\%)$ & $0 \%$ & $30 \%$ & 0 & $3,7 \%$ \\
\hline
\end{tabular}

Berdasarkan Tabel 2 di atas, data pada Tabel 2 memperlihatkan bahwa persentase ketuntasan pre-test hasil belajar ranah pengetahuan kelas eksperimen sama dengan kelas kontrol yaitu $0 \%$, sedangkan persentase ketuntasan post-test hasil belajar ranah pengetahuan kelas eksperimen lebih besar yaitu 30\% daripada kelas kontrol yaitu $3,7 \%$. Hal ini menunjukkan bahwa peserta didik kelas eksperimen dapat mencapai ketuntasan daripada kelas kontrol.

\section{B. Hasil analisis deksriptif $\mathrm{N}$-gain hasil belajar ranah pengetahuan peserta didik}

Analsis ini membandingkan antara kelas eksperimen dan kontrol setelah diberi perlakuan. Hasil belajar (pengetahuan) post-test kelas eksperimen lebih tinggi daripada kelas kontrol. Setelah dihitung menggunakan uji-t terdapat perbedaan yang signifikan antara kelas eksperimen dengan kelas kontrol. Perbedaan ini karena adanya pengaruh dari pembelajaran inkuiri pada kelas eksperimen yang mengharuskan peserta didik berprilaku seperti penemu daripada model inkuiri konfirmasi. Hal ini dapat dilihat pada uji-t dan nilai $\mathrm{N}$-Gain kedua kelas yang dapat di Tabel 3 dan Tabel 4.

Tabel 3 Uji-t data pretest dan post-test hasil tes ranah pengetahuan

\begin{tabular}{cccccccc}
\hline Hasil & Kelas & $\mathbf{d B}$ & $\mathbf{X}$ & $\mathbf{S D}^{\mathbf{2}}$ & $\mathbf{T}_{\text {Hitung }}$ & $\mathbf{T}_{\text {Tabel }}$ & Keterangan \\
\hline \multirow{2}{*}{ Pre-test } & Eksperimen & 19 & 26,68 & 146,813 & \multirow{2}{*}{0,8} & \multirow{2}{*}{2,011} & \multirow{2}{*}{ Tidak Signifikan } \\
& Kontrol & 26 & 23,96 & 106,976 & & & \\
\multirow{2}{*}{ Post-test } & Eksperimen & 19 & 69,17 & 157,213 & \multirow{2}{*}{4,67868} & 2,011 & \multirow{2}{*}{ Signifikan } \\
& Kontrol & 26 & 48,17 & 319,407 & & & \\
\hline
\end{tabular}

Tabel 4 Interpretasi $N$-gain hasil tes ranah pengetahuan

\begin{tabular}{ccc}
\hline Kelas & Rata-rata $N$-gain & Kategori \\
\hline Inkuiri terbimbing & 0,57 & Sedang \\
Inkuiri konfirmasi & 0,36 & Sedang \\
\hline
\end{tabular}


Berdasarkan Tabel 4 terlihat bahwa nilai $N$-gain kelas eksperimen lebih tinggi jika dibandingkan dengan kelas kontrol. Sehingga menunjukkan kelas eksperimen mengalami peningkatan hasil belajar lebih besar dibandingkan kelas kontrol karena menerapkan model inkuiri terbimbing. Hasil temuan yang diperoleh juga sesuai oleh penelitian Andrianie, Sudarmin, \& Wardani (2018) dan Mualifah, Suyono, \& Yuanita (2013) penurunan miskonsepsi pada peserta didik karena pembelajaran inkuiri dimana peserta didik memahami materi pembelajaran melalui kegiatan penemuan dan dapat merokontruksi konsep yang benar (true concept) dengan salah satu sintak yang ada dimodel inkuiri terbimbing. Model inkuiri terbimbing memiliki enam tahapan yaitu: orientasi, merumuskan masalah, merumuskan hipotesis, mengumpulkan data, menguji hipotesis dan merumuskan kesimpulan (Hosnan, 2014).

Pada orientasi, ditahap ini guru merangsang pemikiran awal peserta didik dengan menyajikan permasalahan dalam LKPD. Tahap merumuskan masalah pada tahap ini peserta didik harus memahami permasalahan yang telah disajikan dalam LKPD terlebih dahulu. Tahap merumuskan hipotesis, peserta didik menganalisis masalah secara relevan berupa jawaban sementara yang logis dan sesuai dengan pemahaman konsep yang telah dimilikinya. Hipotesis yang diperoleh kemudian diuji melalui percobaan.

Tahap mengumpulkan data yang diawali dengan merancang percobaan kemudian peserta didik melakukan praktikum untuk membuktikan hipotesis dan memperoleh informasi. Miskonsepsi dapat direkontruksi pada tahap ini yaitu dengan adanya kegiatan praktikum dimana peserta didik dilatih belajar mandiri untuk menemukan konsep maupun fakta. Hal ini sesuai dengan pernyataan Masitoh, Marjono, \& Ariyanto (2017) praktikum memberikan kesempatan pada peserta didik untuk berlatih mengembangkan keterampilan investigasi dan mendapatkan pengalaman yanng nyata mengenai fenomena alam untuk memahami pembelajaran konsep.

Tahap menguji hipotesis yaitu peserta didik dibimbing untuk menganalisiis informasi dan data yang telah dimiliki peserta didik pada tahapan sebelumnya, dan tahap terakhir, peserta didik diminta membuat kesimpulan dari hasil kegiatan praktikum dan menganalisis data sesuai dengan hipotesis yang benar dengan bimbingan oleh guru untuk meningkatkan hasil belajar.

Berikut ini djabarkan seberapa besar hasil belajar peserta didik dapat di tingkatkan oleh bantuan model inkuiri terbimbing pada kelas eksperimen. Secara ringkas kelima belas indikator perbandingannya terdapat pada Gambar 1 perbandingan hasil persentase tingkat hasil belajar setiap indikator untuk kedua kelas pada post-test. 


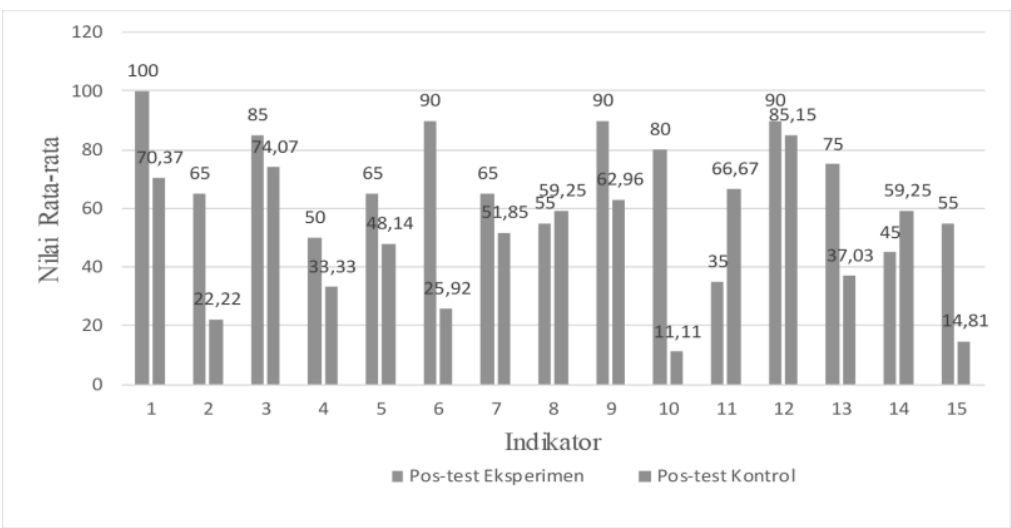

Gambar 1Tingkat pemahaman hasil belajar ranah pengetahuan

Indikator meliputi

a. Indikator 1 menentukan larutan, koloid, dan suspensi berdasarkan data hasil pengamatan.

b. Indikator 2 mengelompokkan tipe system koloid.

c. Indikator 3 menganalisis suatu larutan dispersi kasar (suspensi), dispersi halus (larutan), dan dispersi koloid.

d. Indikator 4 yaitu menganalisis jenis koloid berdasarkan fase terdispersi dan fase pendispersi.

e. Indikator 5 mengelompokkan jenis koloid berdasarkan fase terdispersi dan fase pendispersi.

f. Indikator 6 mendeskripsikan sifat-sifat koloid (efek Tyndall, gerak Brown, koagulasi dan adsorpsi).

g. Indikator 8 mengelompokkan tipe sistem koloid.

h. Indikator 9 mengelompokkan tipe sistem koloid.

i. Indikator 10 menganalisis sifat koloid yang terjadi pada kehidupan sehari-hari.

j. Indikator 11 menerapkan pembuatan koloid dalam kehidupan sehari-hari.

$\mathrm{k}$. Indikator 12 mendeskripsikan peranan koloid di industri kosmetik, makanan dan farmasi.

1. Indikator 13 menyimpulkan pembuatan koloid dalam kehidupan sehari-hari.

m. Indikator 14 mendeskripsikan peranan koloid di industri kosmetik, makanan dan farmasi.

n. Indikator 15 mendeskripsikan peranan koloid di industri kosmetik, makanan dan farmasi.

Tingkat pemahaman kelas eksperimen pada setiap indikator lebih tinggi dibanding kelas kontrol. Dari kelima belas indikator, diurutkan tingkat pemahaman yang tertinggi yaitu indikator 1 yaitu materi menentukan larutan, koloid, dan suspensi berdasarkan data hasil pengamatan dan tingkat pemahaman terendah pada indikator 15 yaitu materi menentukan bahan/zat berupa koloid dalam industri farmasi, kosmetik, bahan makanan, dan lain-lain.

Hasil tes untuk sampel eksperimen dan sampel kontrol yang mengalami peningkatan hasil belajar tidak terlepas dari pengaruh model inkuiri terbimbing yang mana peserta didik dilatih secara terus-menerus menemukan jawaban dari setiap permasalahan melalui LKPD mana materi sistem koloid merupakan salah satu materi kimia yang seringkali diabaikan padahal koloid (Chairisa, Sholahuddin, \& Leny, 2016). 


\section{c. Data hasil observasi hasil belajar ranah keterampilan peserta didik}

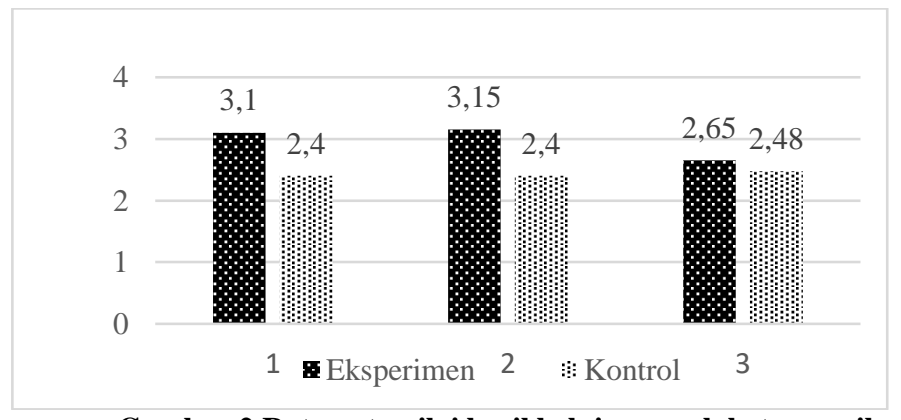

Gambar 2 Rata-rata nilai hasil belajar ranah keterampilan

Berdasarkan Gambar 2 terlihat bahwa pada kelas eksperimen memiliki ratarata nilai lebih tinggi menggunakan inkuiri terbimbing disetiap aspek hasil belajar ranah keterampilan dibandingkan kelas kontrol. Hal ini sejalan dengan penelitian yang dilakukan oleh Imaniarti, Prihandono, \& Supriadi (2015). Aspeknya keterampilan meliputi; (1) Cara melipat kertas saring secara benar + Cara menyaring larutan sampel uji; (2) Cara menggunakan gelas ukur + Cara mengarahkan cahaya lampu senter ke larutan uji; (3) Cara menggunakan pipet tetes + Cara menggerus bahan uji (gula + serbuk belerang).

\section{d. Data hasil observasi hasil belajar ranah sikap peserta didik}

Penelitian ini juga menilai sikap peserta didik dari kelas eksperimenmaupun kelas kontrol yang terdiri dari rasa ingin tahu, tanggung jawab danbekerjasama.

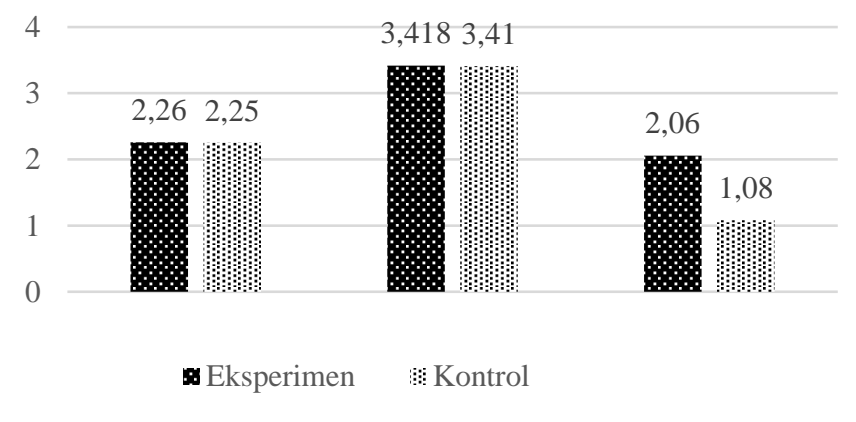

Gambar 3 nilai rata-rata hasil belajar ranah sikap

Berdasarkan Gambar 3 terlihat bahwa pada kelas eksperimen memiliki ratarata lebih tinggi sejalan dengan penelitian yang dilakukan oleh Sidik, Masykuri, \& Mulyani (2016) mengenai persentase afektif peserta didik pada setiap pertemuan semakin meningkat.disetiap aspek hasil belajar ranah sikap dibanding kelas kontrol cenderung bersifat teacher center dan tidak memberi kesempatan kepada peserta didik untuk menggali pengetahuannya sehingga pembelajaran bersifat kurang dinamis dan fleksibel sejalan dengan penelitian Restami, Kusuma, \& Pujiani (2013) dan Indrayanti, Ariani, \& Haryono (2014) cenderung lebih pasif bahkan banyak yang peserta didik yang mendengarkan penjelasan guru namun tidak benar-benar memperhatikan materi yang disampaikan. 


\section{SIMPULAN}

Penelitian ini dapat disimpulkan peserta didik kelas XI IPA SMA PGRI 6 Banjarmasin Terdapat perbedaan hasil belajar antara peserta didik yang belajar menggunakan model pembelajaran inkuiri terbimbing dan yang belajar menggunakan model inkuiri konfirmasi pada materi sistem koloid. Adanya perbedaan hasil belajar yang signifikan pada penerapan model inkuiri terbimbing dengan model inkuiri konfirmasi materi larutan penyangga. ketuntasan 30\% untuk kelas eksperimen dan sebanyak ketuntasan 3,7\% untuk kelas kontrol.

\section{DAFTAR RUJUKAN}

Ambarsari, W., Santosa, S., \& Maridi, M. (2013). Penerapan pembelajaran inkuiri terbimbing terhadap keterampilan proses sains dasar pada pelajaran biologi peserta didik kelas VIII SMP Negeri 7 Surakarta. Jurnal Pendidikan Biologi, 81-95.

Andrianie, D., Sudarmin, \& Wardani, S. (2018). Representasi untuk mereduksi miskonsepsi pada siswa materi redoks melalui penerapan model pembelajaran inkuiri terbimbing berbantuan LKS. jurnal chemistry in education , 7 (2), 6976.

Arief, H. S., Maulana, \& Sudin, A. (2016). Meningkatkan Motivasi Belajar Melalui Pendekatan Problem Based Learning (PBL). Jurnal Pena Ilmiah, 141-150.

Arikunto, S. (2015). Dasar-Dasar Evaluasi Pendidikan. Jakarta: Bumi Aksara.

Chairisa, N., Sholahuddin, A., \&Leny. (2016). Perbedaan Literasi Ilmiah dan Hasil Belajar Pada Materi Sistem Koloid Antara Pembelajaran yang Menggunakan Model Inkuiri Terbimbing Dengan Metode Eksperimen Riil dan Eksperimen Animasi. Jurnal Quantum Inovasi Pendidikan Sains, 156-175.

Dianta, N., \& Supraptono, E. (2016). Penerapan SFAE Berbantu Prezi Terhadap Motivasi Belajar dan Ketrampilan Siswa Dalam Mengoperasikan Software Spreadsheet. Jurnal Penelitian Pendidikan Indonesia , 1-7.

Fajarianingtyas, D., \& Yuniastri, R. (2015). Upaya reduksi miskonsepsi siswa pada konsep reaksi redoks melalui model guided inquiry di SMA Negri I Sumenep. jurnal lentera sains , 5 (2), 37-46.

Hidayati, N., Leny, \& Iriani, R. (2018). Pengaruh Model Pembelajaran Inquri Based Learning Dengan Pendekatan Flipped Classroom Terhadap Self effi Efficacy Dan Hasil Belajar Kesetimbangan Ion Dalam Larutann Garam. Prosiding Seminar Nasional Pendidikan Kimia , 99-107.

Hosnan. (2014). Pendekatan Saintifik dan Kontekstual dalam Pembelajaran Abad 21. Bogor: Ghalia Indonesia.

Indrayanti, N. D., Ariani, S. R. D., \&Haryono. (2014). Studi Komparasi Metode Pembelajaran TGT dan STAD terhadap Prestasi Belajar Pada Materi Larutan Elektrolit dan Non Elektrolit ditinjau dari Sikap Ilmiah Siswa Kelas X di SMA Negeri 7 Surakarta Tahun Pelajaran 2013/2014. Jurnal Pendidikan Kimia (JPK), 3(4), 109-117.

Masitoh, I. D., Marjono, \& Ariyanto, J. (2017). Pengaruh Model Pembelajaran Inkuiri Terbimbing terhadap Kemampuan Berpikir Kritis Peserta didik Kelas X MIA pada Materi Pencemaran Lingkungan di Surakarta. Bioedukasi, X(1), 71-79.

Mualifah, Suyono, \& Yuanita. (2013). Mencegah Miskonsepsi Siswa pada Kesetimbangan Kimia Menggunakan Model Inkuiri Terbuka dan Remediasi Menggunakan Strategi Conceptual Change. Jurnal UNESA , 3 (1), 306-311. 
Paralita, F., Eny, E., \&Rahmat, R. (2015). Pengaruh Model Inkuiri Terbimbing Terhadap Hasil Belajar Materi Larutan Elektrolit dan Non Elektrolit di SMA. Jurnal Pendidikan dan Pembelajaran. 4(11).

Restami, M. P., Kusuma, K., \&Pujiani, M. (2013). Pengaruh Model Pembelajaran POE (Predict-Observe-Explain) terhadap Pemahaman Konsep dan Sikap Ilmiah ditinjau dari Gaya Belajar Siswa. e-Journal Program Pascasarjana Universitas Pendidikan Ganesha, 4(3), 211-218.

Sidik, T. I., Masykuri, M., \&Mulyani, B. (2016). Penerapan Model Pembelajaran Teams Games Tournament (TGT) Dilengkapi Adobe Flash Untuk Meningkatkan Aktivitas dan Prestasi Belajar Siswa Pada Materi Kelarutan dan Hasil Kali Kelarutan Kelas XI IPA di SMAN 2 Boyolali Tahun Pelajaran 2014/2016. Jurnal Pendidikan Kimia, 5(1), 41-45.

Sugiyono. (2015). Metode Penelitian pendidikan pendekatan Kuantitatif, Kualitatif dan $R \& D$. Bandung: ALFABETA.

Sukma, Komariyah, L., \& Syam, M. (2016). Pengaruh Model Pembelajaran Inkuiri Terbimbing (Guided Inquiry) dan Motivasi Terhadap Hasil Belajar Fisika Peserta didik. Jurnal Saintifika , 59-63.

Supardi. (2013). Aplikasi Statistika dalam Penelitian: Konsep Statistika yang Lebih Komprehensif. Jakarta: Change Publication.

Syafitri, W. (2010). Analisis Keterampilan Proses Sains Siswa Melalui Pendekatan Inkuiri Pada Konsep Sistem Koloid. Skripsi . 